\title{
Bimbingan Individu sebagai Upaya untuk Meningkatkan Kedisiplinan Mengikuti Tata Tertib Sekolah
}

\author{
Nyoman Purnayasa \\ Sekolah Menengah Pertama N 2 Singaraja, Singaraja, Indonesia
}

A R T I C L E I N F O

Article history:

Received 19 Maret

2018

Received in revised

form

30 Maret 2018

Accepted 12 April

2018

Available online 20

Mei 2018

Kata Kunci:

Bimbingan Individu,

Kedisiplinan

Keywords:

Individual Guidance,

Discipline

\begin{abstract}
A B S T R A K
Tujuan penelitian tindakan kelas ini adalah untuk mengetahui apakah model bimbingan individu dapat meningkatkan kedisiplinan siswa dalam mengikuti tata tertib sekolah. Subyek penelitian ini adalah siswa SMP Negeri 2 Singaraja tahun pelajaran 2016/2017, kelas IX 1 sebanyak 36 orang. Metode pengumpulan data yang digunakan adalah metde observasi dan pencatatan dokumen. Metode analisis datanya adalah deskriptif. Hasil yang diperoleh dari penelitian ini adalah bimbingan individu dapat meningkatkan kedisiplinan siswa dalam mengikuti tata tertib sekolah. Ini terbukti dari hasil yang diperoleh pada siklus I meningkat dibandingkan dengan data awal, yaitu dari $75 \%$ meningkat menjadi $80 \%$. Setelah diadakan bimbingan individual serta perbaikan pada kelemahan-kelemahan yang ada pada siklus I ternyata terjadi peningkatan dari siklus I ke siklus II, yaitu dari $80 \%$ meningkat menjadi 98\%. Dapat disimpulkan bahwa bimbingan individu dapat meningkatkan kedisiplinan siswa dalam mengikuti tata tertib sekolah.
\end{abstract}

\section{A B S T R A C T}

This research was conducted in SMP Negeri 2 Singaraja on the students of class IX 1 in odd semester, academic year 2016/2017 with condition of student discipline still less appropriate with initial data reach $75 \%$. The purpose of this action research study is to know whether the individual guidance model can improve discipline students in following school rules. Data collection method was observation. Data analysis method was descriptive for qualitative data. The result obtained from this research was individual guidance can improve student discipline in following school order. This is evident from the results obtained in the first cycle increased $80 \%$ of the initial data. After the individual guidance and improvement on the weaknesses that exist in cycle I was increased from Cycle I to Cycle II up to $98 \%$. Conclusion obtained from this study is individual guidance can improve student discipline in following school rules 


\section{Pendahuluan}

Sekolah tidak dapat melepaskan diri dari situasi kehidupan masyarakat dan mempunyai tanggung jawab untuk membantu para siswa, baik sebagai pribadi maupun sebagai calon anggota masyarakat. Sebagai suatu lembaga pendidikan formal, sekolah bertanggung jawab untuk mendidik dan menyiapkan siswa agar berhasil menyesuaikan diri di masyarakat dan mampu menyelesaikan semua masalah yang dihadapinya. Kegiatan belajar mengajar merupakan salah satu diantara kegiatan yang diberikan oleh sekolah. Namun, kegiatan itu saja belum cukup memadai dalam menyiapkan siswa untuk terjun ke masyarakat dengan berhasil. Dalam mengikuti pendidikan di sekolah, hendaknya siswa merasa nyaman dan dapat berinteraksi yang baik dengan semua siswa (Dewi, 2014). Oleh karena itu, sekolah hendaknya memberikan bantuan secara pribadi kepada siswa agar mampu memecahkan masalah pribadi yang dihadapinya. Siswa hendaknya dibantu agar apa yang mereka terima di sekolah dapat memberikan bekal untuk menjadi anggota masyarakat yang mandiri dan mampu memecahkan masalah-masalah yang dihadapinya. Di dalam situasi inilah, Bimbingan dan Konseling akan sangat diperlukan sebagai suatu bentuk bantuan kepada siswa. Program Bimbingan dan Konseling membantu berhasilnya program pendidikan pada umumnya.

Pendidikan mempunyai peran yang sangat penting dalam meningkatkan kualitas sumber daya manusia sebagai salah satu pilar pembangunan suatu negara (Megantari, 2014). Sesuai dengan kebijakan pemerintah, pendidikan diartikan sebagai suatu usaha sadar untuk mengembangkan kepribadian yang berlangsung di sekolah maupun di luar sekolah dan berlangsung seumur hidup. Sedangkan tujuan pendidikan sebagaimana dikemukakan dalam GBHN adalah " Untuk meningkatkan ketaqwaan terhadap Tuhan Yang Maha Esa, kecerdasan, keterampilan, mempertinggi budi pekerti, memperkuat kepribadian, mempertebal, semangat kebangsaan, dan cinta tanah air, agar dapat menumbuhkan manusia-manusia pembangunan yang dapat membangun dirinya sendiri serta bersama-sama bertanggung jawab atas pembangunan bangsa. Dari pengertian dan tujuan diatas, jelas yang menjadi tujuan inti dari pendidikan adalah pengembangan kepribadian dari setiap anak didik secara pribadi. Dengan demikian setiap kegiatan proses pendidikan diarahkan kepada tercapainya pribadi-pribadi yang berkembang dan disiplin, maka kegiatan pendidikan hendaknya bersifat menyeluruh yang tidak hanya berupa kegiatan instruksional (pengajaran), akan tetapi meliputi kegiatan yang menjamin bahwa setiap anak didik secara pribadi mendapat layanan sehingga akhirnya dapat berkembang secara optimal. Dalam pendidikan formal, belajar menunjukkan adanya perubahan yang sifatnya positif sehingga pada tahap akhir akan didapat keterampilan,pengalaman, kecakapan, dan pengetahuan baru. Belajar adalah kegiatan berproses dan merupakan unsur yang sangat fundamental dalam menyelenggarakan jenis dan jenjang pendidikan, hal ini berarti keberhasilan pencapaian tujuan pendidikan sangat tergantung pada keberhasilan proses belajar siswa di sekolah dan lingkungan sekitarnya (Diatmika, 2017).

Kegiatan pendidikan yang diinginkan seperti tersebut di atas, adalah kegiatan pendidikan yang ditandai dengan pengadministrasian yang baik, kurikulum beserta proses belajar mengajar yang memadai, dan layanan pribadi kepada anak didik melalui bimbingan. Serta dalam proses belajar mengajar perlu, penghargaan atau pujian terhadap perbuatan yang baik atau prestasi dari siswa merupakan hal yang sangat diperlukan sehingga siswa terus berusaha berbuat lebih baik, misalnya guru tersenyum atau mengucapkan katakata bagus kepada siswa yang dapat mengerjakan tugas dengan baik akan sangat besar pengaruhnya (Nursetya, 2014).

Dalam hubungan inilah bimbingan mempunyai peranan yang amat penting dalam pendidikan, yaitu membantu setiap pribadi anak didik agar berkembang secara optimal dan tingkat kedisiplinan yang tinggi. Bimbingan, sebagai upaya pendidikan, diartikan sebagai proses bantuan kepada individu untuk mencapai tingkat perkembangan diri secara optimum di dalam navigasi hidupnya secara mandiri (Bhakti, 2015). Setiap kegiatan sangat memerlukan kedisiplinan karena kedisiplinan adalah kunci berhasil atau gagalnya suatu kegiatan (Yuliyantika, 2017). Disiplin dapat tumbuh dan dibina melalui latihan, pendidikan atau penanaman kebiasaan yang harus dimulai sejak dalam lingkungan keluarga, mulai pada masa kanakkanak dan terus berkembang sehingga menjadi disiplin yang kuat (Widana, 2016). Disiplin adalah suatu cara untuk membantu anak agar dapat mengembangkan pengendalian diri (Erlina, 2016). Disiplin merupakan salah satu kecakapan hidup yang sangat penting dan perlu dimiliki oleh setiap orang guna mencapai kesuksesan dalam hidupnya, tidak hanya kesuksesan dalam belajar tetapi juga kesuksesan dalam hidup bermasyarakat (Simanungkalit, 2017). Menurut Wiyani (dalam Hardhianah dan Christiana, 2012:02) menyatakan "penanaman disiplin yang tepat dilakukan adalah sejak usia dini karena jika perilaku disiplin tersebut dibentuk kepada anak sejak dini nantinya akan menjadi modal yang berharga bagi anak saat mereka dewasa". Tingkat kedisiplinan yang tinggi tercermin pada pribadi anak didik yang berkembang secara akademik, psikologis maupun sosial. Disiplin belajar dalam pribadi peserta didik akan 
memberikan dampak pada proses pembelajaran yang efektif, meningkatnya prestasi belajar, dan menunjukkan tugas perkembangan yang baik (Isnaini, 2015).

Kenyataan yang dihadapi dunia pendidikan di Indonesia pada umumnya, masih terdapat kecendrungan bahwa pendidikan belum sepenuhnya dapat membantu perkembangan kepribadian dan kedisiplinan anak didik secara optimal. Secara realita banyak masalah-masalah rumit yang sering dialami oleh setiap siswa sebenarnya berasal dari dalam dirinya (Hanum, 2015). Hal ini nampak antara lain dalam gejala-gejala: ugal-ugalan, lambat masuk sekolah, melanggar tata tertib sekolah putus sekolah, tinggal kelas, lambat belajar, berprestasi rendah, dan sebagainya. Secara psikologis masih banyak adanya gejalagejala perkembangan kepribadian yang kurang matang, kurang percaya diri, kecemasan, putus asa, bersikap santai, kurang responsife, ketergantungan, pribadi yang tidak seimbang, dan sebagainya.

Kondisi secara umum yang terjadi di SMP Negeri 2 Singaraja, khususnya di kelas IX 1 rata-rata kedisiplinan siswa masih kurang dalam penerapan tata tertib sekolah dan seringnya terjadi pelanggaran terhadap tata tertib tersebut. Sehubungan dengan itu, layanan bimbingan individual dirasakan amat berperanan dalam membantu proses dan pencapaian tujuan pendidikan secara paripurna, dan para siswa diharapkan mampu menyesuaikan diri dengan setiap perkembangan pendidikan yang terjadi untuk mencapai sukses yang berarti dalam keseluruhan proses belajarnya.

Dari kesenjangan-kesenjangan yang terjadi, maka selaku guru bimbingan konseling, peneliti berinisiatif untuk menerapkan bimbingan individu. Sehubungan dengan hal tersebut, maka tujuan penelitian ini adalah untuk mengetahui seberapa tinggi meningkatnya kedisiplinan siswa yang dalam mengikuti tata tertib yang terjadi setelah dilakukan bimbingan individu. Manfaat penelitian ini, yaitu sebagai berikut. (1) Bagi siswa, penelitian dengan bimbingan individu dapat meningkatkan kedisiplinan siswa dalam mengikuti tata tertib sekolah. (2) Bagi guru, hasil penelitian ini dapat dipergunakan sebagai alternatif solusi penanggulangan permasalahan kedisipinan siswa mengikuti tata tertib sekolah. (3) Bagi sekolah, hasil penelitian dapat digunakan sebagai referensi dalam penanggulangan rendahnya disiplin siswa dalam mengikuti tata tertib sekolah. Manfaat yang diharapkankan dengan dilaksanakannya penelitian ini yaitu disiplin siswa dapat dipertahankan bahkan ditingkatkankan.

Menurut Winkel \& Sri Hastuti (2006: 118-119) bimbingan individu berarti bimbingan dalam memahami keadaan batinnya sendiri dan mengatasi berbagai pergumulan dalam batinnya sendiri, dalam mengatur diri sendiri dibidang kerohanian, perawatan jasmani, pengisian waktu luang, penyaluran nafsu seksual dan sebagainya. Sedangkan Dewa Ketut Sukardi (1997: 23) menjelaskan bahwa bimbingan pribadi berarti membantu siswa menemukan dan mengembangkan pribadi yang beriman kepada Tuhan Yang Maha Esa, mantap dan mandiri serta sehat jasmani dan rohani. Dari pengertian di atas, dapat disimpulkan bahwa bimbingan pribadi adalah bimbingan yang dilakukan untuk membantu konseli atau siswa dalam memahami keadaan dirinya baik fisik maupun psikis, memahami akan makna diri sebagai makhluk Tuhan serta pemahaman akan segala kelebihan dan potensi diri yang dimiliki demi tercapainya kualitas hidup yang lebih baik.

Dalam penelitian ini, jika peserta didik yang disiplinnya rendah tetap dibiarkan, maka akan sulit mengikuti pembelajaran dan sulit pula mengikuti pendidikan berikutnya. Maka dari itu, pemberian bimbingan individu dapat meningkatkan disiplin siswa dalam menaati tata tertib sekolah. Tahapan pelaksanaan bimbingan individu yang diberikan kepada siswa, yaitu sebagai berikut. Pertama, dari awal siswa dibimbing dengan cara membangun hubungan konseling dengan guru BK/konselor. Kedua, dilakukan penjelajahan masalah secara mendalam agar klien mempunyai persfektif dan alternative baru terhadap masalah yang sedang dihadapi. Ketiga, pada tahap akhir, membuat kesimpulan mengenai hasil proses konseling. Dengan pelaksanaan yang benar mengikuti aturan-aturan yang ada yang dilakukan melalui bimbingan individu dapat diyakini kedisiplinan siswa dalam mengikuti tata tertib sekolah dapat ditingkatkan.

\section{Metode}

Penelitian ini merupakan penelitian tindakan, yang dilaksanakan dalam dua siklus, masing masing siklus terdiri dari empat tahap, yaitu: perencanaan, pelaksanaan tindakan, observasi, dan refleksi. Dimulai dengan melihat adanya masalah di lapangan. Dengan adanya masalah di lapangan, maka peneliti mulai membuat perencanaan I dan selanjutnya melaksanakannya, mengamati atau mengumpulkan data, dan melakukan refleksi I. Jika masih terdapat permasalahan setelah siklus I dilaksanakan, selanjutnya dibuat perencanaan siklus II. Setelah perencanan siklus II dilakukan, kemudian dilanjutnya dengan pelaksanaan, pengamatan atau pengumpulan data, dan refleksi. Apabila permasalahan belum selesai dilanjutkan dengan siklus berikutnya. Subyek Penelitian tindakan bimbingan konseling ini adalah siswa kelas IX 1 sebanyak 36 orang pada SMP Negeri 2 Singaraja. Sedangkan obyek penelitian ini peningkatan disiplin siswa dalam mengikuti tata tertib sekolah dengan bimbingan individu. Penelitian ini dilakukan pada 
semester ganjil tahun pelajaran 2016/2017, selama satu semester dari bulan Juli sampai dengan bulan Desember tahun 2016.

Metode yang digunakan untuk mengumpulkan data dalam penelitian ini adalah metode observasi dan pencatatan dokumen. Setelah data diperoleh, selanjutnya data di analisis secara deskriftif kuantitatif dan kualitatif. Data disajikan dalam bentuk rata-rata mengikuti tata tertib sekolah yang dikatagorikan menjadi amat kurang (E), kurang (D), cukup (C), baik (B), amat baik (AB).

Penelitian ini dianggap berhasil jika hasil penelitian pada siklus I maupun siklus II telah mencapai nilai rata-rata 85 \%. Acuan katagori hasil penilaian kedisiplinan siswa adalah seperti Tabel 1.

Tabel 1. Konversi skor penilaian kedisiplinan

\begin{tabular}{cc}
\hline PERINGKAT & NILAI \\
\hline AMAT BAIK (A) & $86-100$ \\
\hline BAIK (B) & $76-85$ \\
\hline CUKUP (C) & $66-75$ \\
\hline KURANG (D) & $56-65$ \\
\hline AMAT KURANG (E) & $46-55$ \\
\hline
\end{tabular}

(Depdiknas, 2009: 92)

\section{Hasil dan Pembahasan}

\section{Hasil}

Untuk memperoleh data yang akurat, subjek penelitian ini adalah siswa yang tidak disiplin atau melanggar tata tertib sekolah. Data ini didapat dari hasil observasi dan catatan dokumen dari guru bimbingan konseling dengan indikator : (1) menggunakan pakaian tidak sesuai aturan, (2) masuk sekolah tidak tepat waktu, (3) giat belajar, (4) rajin dalam menyelesaikan tugas, (5) menggunakan sepatu dan ikat pinggang, (6) rambut dicukur rapi, (7) betul-betul mendengarkan dan memperhatikan guru pada saat bimbingan, (8) jawaban yang disampaikan siswa pada saat bimbingan betul merupakan jawaban yang muncul atas dasar akal sehat. Data siswa yang tidak disiplin atau melanggar tata tertib sekolah dapat dilihat dari Tabel 2.

Tabel 2. Indikator observasi dan pencatatan dokumen

\begin{tabular}{clc}
\hline No & \multicolumn{1}{c}{ Indikator } & Jumlah Siswa \\
\hline 1 & Menggunakan pakaian tidak sesuai aturan & 25 \\
\hline 2 & Masuk sekolah tidak tepat waktu & 25 \\
\hline 3 & Giat belajar & 19 \\
\hline 4 & Rajin dalam menyelesaikan tugas & 25 \\
\hline 5 & Menggunakan sepatu dan ikat pinggang & 20 \\
\hline 6 & Rambut dicukur rapi & 20 \\
\hline 7 & Betul-betul mendengarkan dan memperhatikan guru pada & 23 \\
\hline & saat bimbingan & 24 \\
\hline & $\begin{array}{l}\text { Jawaban yang disampaikan siswa pada saat bimbingan betul } \\
\text { merupakan jawaban yang muncul atas dasar akal sehat }\end{array}$
\end{tabular}

Sumber: hasil penghitungan data 2017

Hasil dari masing-masing kategori adalah: A. Kategori pakaian sesuai aturan sekolah hasilnya adalah 25 siswa belum sesuai dengan aturan. B. Kategori masuk sekolah/kelas tepat waktu hasilnya adalah 25 siswa belum tepat waktu masuk sekolah/kelas. C. Kategori giat belajar/giat mengikuti bimbingan hasilnya adalah adalah 19 siswa belum giat mengikuti bimbingan. D. Kategori rajin menyelesiakan tugas hasilnya adalah adalah 25 siswa belum rajin menyelesaikan tugas. E. Kategori menggunakan sepatu dan ikat pinggang hasilnya adalah adalah 20 siswa belum menggunakan sepatu dan ikat pinggang sesuai ketentuan sekolah. F. Kategori rambut dicukur rapi hasilnya adalah adalah 20 siswa belum mencukur rambutnya dengan rapi. G. Kategori betul-betul mendengarkan dan memperhatikan guru pada saat bimbingan hasilnya adalah adalah 23 siswa belum disiplin mendengarkan dan memperhatikan guru. H. Kategori jawaban yang disampaikan siswa pada saat bimbingan betul merupakan 
jawaban yang muncul atas dasar akal yang sehat hasilnya adalah adalah 24 siswa belum mampu menyampaikan jawaban dengan baik.

Dari data di atas, dapat direfleksi bahwa hanya 2 siswa yang kedisiplinannya amat baik, 17 siswa yang kedisiplinannya baik, 14 siswa yang kedisiplinnnya cukup, 1 siswa kedisiplinannya kurang dan 2 siswa kedisplinannya amat kurang sehingga perlu pembinaan lanjutan. Selanjutnya, dari rata-rata nilai yang telah diperoleh berdasarkan hasil observasi, yaitu 75\% dari seluruh siswa memperoleh rata-rata kualifikasi kedisiplinnya cukup. Oleh karenanya, bimbingan ini masih perlu untuk dilanjutkan ke siklus berikutnya. Perolehan data awal yang dapat diperoleh dari observasi yang dilaksanakan oleh guru bimbingan konseling disajikan dalam tabel tersebut di atas.

Siswa yang menunjukkan tidak disiplin ditetapkan sebagai subyek penelitian yang akan diberikan bimbingan individual. Untuk memperoleh data yang akurat mengenai siswa yang tidak menunjukkan kedisiplinan akan dijadikan subyek penelitian, yaitu dengan melihat hasil observasi dan catatan dokumen dari guru bimbingan konseling yang dipakai subyek penelitian, dengan indikator : (1) menggunakan pakaian tidak sesuai aturan, (2) masuk sekolah tidak tepat waktu, (3) giat belajar, (4) rajin dalam menyelesaikan tugas, (5) menggunakan sepatu dan ikat pinggang, (6) rambut dicukur rapi, (7) betul-betul mendengarkan dan memperhatikan guru pada saat bimbingan, (8) jawaban yang disampaikan siswa pada saat bimbingan betul merupakan jawaban yang muncul atas dasar akal sehat. Hasil perencanaan, peneliti menyusun Rencana Pelaksanaan Bimbingan dan Konseling yang akan digunakan untuk membimbing siswa yang bermasalah kedisiplinannya. Melihat data awal yang tidak sesuai harapan, peneliti berkonsultasi dengan teman-teman guru BK merencanakan bimbingan yang paling tepat untuk menyelesaikan masalah yang ada, menentukan waktu bimbingan, menyusun format observasi, merencanakan bahan-bahan pendukung bimbingan, merancang skenario bimbingan yang akan digunakan. (1) Pengelolaan kelas dengan membimbing siswa sesuai jadwal yang sudah ada sambil juga membimbing mereka secara individual. (2) Pada saat membimbing, peneliti mengisi blanko observasi yang telah dibuat untuk memberi penilaian. (3) Membimbing dengan cara yang sangat giat, mengajar materi, mengajak siswa mau melakukan hal-hal yang baik, memberi pengertian-pengertian tentang tata tertib sekolah.

\section{Pembahasan}

Data yang dikumpulkan pada data awal adalah berupa observasi dan pencatatan dokumen terhadap siswa melanggar tata tertib sekolah. Observasi adalah dengan mencatat perilaku siswa untuk mengetahui hambatan yang muncul sebagai bahan refleksi pelaksanaan siklus I. Untuk hasil dari bimbingan terhadap siswa diamati secara berkelanjutan dengan peneliti terus memperhatikan semua siswa yang diteliti, gerak-gerik mereka, pakaian mereka, kehadiran pada pagi hari dan terus memantau dengan lembar observasi yang telah peneliti siapkan. Hasil observasi selama satu bulan dapat disampaikan sebagai berikut: dari 36 siswa yang diteliti masih ada 25 siswa yang belum disiplin seperti: lambatnya masuk kelas, lambat dalam mengambil kesimpulan, lebih egosentris, masih terbawa kebiasaan lama.

Refleksi merupakan kajian secara menyeluruh tindakan yang telah dilakukan berdasar data yang telah terkumpul, kemudian dilakukan evaluasi guna penyempurnaan tindakan. Refleksi menyangkut analisis, sintesis, dan penilaian terhadap hasil pengamatan atas tindakan yang dilakukan (Hopkin, 1993 dalam Suharsimi Arikunto, Suhardjono, Supardi, 2006: 80). Sehubungan dengan analisis ini adalah analisia kualitatif maka yang dibuat adalah deskripsi terhadap apa yang telah dilaksanakan dengan cara memberi gambaran-gambaran, pertimbangan-pertimbangan, komentar-komentar, pengklasifikasian data, mengkatagorikan, mencek validitas internal dan external, mencari hubungan dan kesimpulan refleksi dibuat dari interpretasi hubungan antar masing-masing katagori dicari maknanya sebagai kesimpulan. Dalam analisis kualitatif boleh saja ada perhitungan pada awalnya, namun pada akhirnya kesimpulan yang digunakan adalah terhadap kualitas dari hasil. Untuk lebih jelasnya, penulis kutipkan pendapat ahli yaitu: Matthew B. Miles dan A. Michael Hubberman (1993: 390) sebagai berikut: Dalam penelitian kualitatif, perhitungan cenderung diabaikan. Ini terjadi karena inti penelitian kualitatif adalah menjangkau sesuatu yang lebih dari sekedar, yang dapat dikatakan kepada kita akan pentingnya kualitas tersebut. Akan tetapi, sebagaimana yang kita perhatikan sebelumnya, terjadi banyak perhitungan pada saat penentuan kualitas tersebut. Refleksi terhadap hasil kualitatif yang didapatkan adalah:

Hasil dari masing-masing kategori adalah: a. Kategori pakaian sesuai aturan sekolah hasilnya adalah 25 siswa belum sesuai dengan aturan. B. Kategori masuk sekolah/kelas tepat waktu hasilnya adalah 25 siswa belum tepat waktu masuk sekolah/kelas. C. Kategori giat belajar/giat mengikuti bimbingan hasilnya adalah adalah 19 siswa belum giat mengikuti bimbingan. D. Kategori rajin menyelesiakan tugas hasilnya adalah adalah 25 siswa belum rajin menyelesaikan tugas. E. Kategori menggunakan sepatu dan ikat pinggang hasilnya adalah adalah 20 siswa belum menggunakan sepatu dan ikat pinggang sesuai ketentuan 
sekolah. F. Kategori rambut dicukur rapi hasilnya adalah adalah 20 siswa belum mencukur rambutnya dengan rapi. G. Kategori betul-betul mendengarkan dan memperhatikan guru pada saat bimbingan hasilnya adalah adalah 23 siswa belum disiplin mendengarkan dan memperhatikan guru. H. Kategori jawaban yang disampaikan siswa pada saat bimbingan betul merupakan jawaban yang muncul atas dasar akal yang sehat hasilnya adalah adalah 24 siswa belum mampu menyampaikan jawaban dengan baik.

Kesimpulan refleksinya adalah 2 siswa yang kedisiplinannya amat baik, 17 siswa yang kedisiplinannya baik, 14 siswa yang kedisiplinnnya cukup, 1 siswa kedisiplinannya kurang dan 2 siswa kedisplinannya amat kurang sehingga perlu pembinaan lanjutan. Selanjutnya dari rata-rata nilai yang telah diperoleh berdasarkan hasil observasi, yaitu $75 \%$ hal ini menunjukkan bahwa seluruh siswa memperoleh rata-rata kualifikasi kedisiplinnya cukup, Oleh karenanya, bimbingan ini masih perlu untuk dilanjutkan ke siklus berikutnya. Perolehan data awal yang dapat diperoleh dari observasi yang dilaksanakan oleh guru bimbingan konseling disajikan dalam tabel tersebut diatas.

Melihat masih ada kelemahan-kelemahan pada data awal, maka perencanaan siklus I ini dibuat lebih matang lagi. Rencana Pelaksanaan Bimbingan dan Konseling disusun ulang, diberi penekanan pada porsi bimbingan yang lebih manusiawi yang lebih banyak agar anak-anak dapat lebih meningkatkan disiplinnya. Disiapkan di Rencana Bimbingan yang lebih baik dengan memberi contoh-contoh pengertian yang lebih dalam, merencanakan bahan-bahan pendukung seperti alat-alat yang lebih berfungsi dan lebih menyenangkan sehingga peserta didik akan lebih mengetahui hal-hal yang baik dan hal-hal yang jelek serta akibatnya dikemudian hari. Dengan persiapan tersebut diharapkan akan terjadi peningkatan disiplin yang lebih maksimal.

Setelah anak-anak dimbimbing, lalu yang masih bermasalah dikumpulkan kembali di satu tempat, mereka mulai dibimbing kembali dengan cara memberitahu hal-hal penting yang merupakan titik kunci peningkatan kedisiplinan. Bimbingan individu diberi penekanan agar siswa secara pelan-pelan mau merubah perilakunya jeleknya. Manusia memang senang bebas, senang acak-acakan, senang dihargai, senang merasa hebat, senang dihormati sehingga perlakuan manusia bisa melebihi batas yang ditentukan. Siswa memang senang dengan hal-hal yang di luar garis tata tertib apabila tidak diberi penekananpenekanan.

Bimbingan terus diupayakan agar anak-anak mengenal mana yang baik dan mana yang buruk dengan memberi contoh-contoh kebenaran nyata yang ada dan memadukan dengan cerita-cerita yang kebenarannya sudah dapat dipercaya. Pelaksanaan observasi dilakukan terus-menerus dengan mengamati keadaan anak-anak, mencek kehadiran mereka pada pagi hari, melihat apakah pakaian yang dikenakan sudah bersih dan rapi, mencek mereka dengan mengamati di kelas, memantau sikap mental mereka dan mencek perubahan yang terjadi pada diri mereka.

Hasil observasi yang dilakukan dapat memberi gambaran yang cukup memuaskan, bahwa selama pengamatan satu bulan lamanya, ada peningkatan yang cukup berarti, semua anak yang diteliti sudah cukup tertib berpakaian, sudah mengenakan ikat pinggang sesuai aturan sekolah, mereka sudah cukup patuh dan menghotmat pada guru-guru, mereka sudah datang dan masuk sekolah tepat waktu, cukuran rambutnya sudah sesuai harapan, mereka dapat berpikir jernih, mereka mampu membuat simpulansimpulan terhadap kebenaran kehidupan yang dialaminya yaitu sebagai murid di Sekolah Menengah Pertama.

Refleksi terhadap hasil pengamatan yang diperoleh, yaitu dari kategori-kategori yang diobservasi: A. Kategori pakaian sesuai aturan sekolah hasilnya adalah 19 siswa belum sesuai dengan aturan. B. Kategori masuk sekolah/kelas tepat waktu hasilnya adalah 19 siswa belum tepat waktu masuk sekolah/kelas. C. Kategori giat belajar/giat mengikuti bimbingan hasilnya adalah adalah 14 siswa belum giat mengikuti bimbingan. D. Kategori rajin menyelesiakan tugas hasilnya adalah adalah 17 siswa belum rajin menyelesaikan tugas. E. Kategori menggunakan sepatu dan ikat pinggang hasilnya adalah adalah 11 siswa belum menggunakan sepatu dan ikat pinggang sesuai ketentuan sekolah. F. Kategori rambut dicukur rapi hasilnya adalah adalah 12 siswa belum mencukur rambutnya dengan rapi. G. Kategori betulbetul mendengarkan dan memperhatikan guru pada saat bimbingan hasilnya adalah adalah 15 siswa belum disiplin mendengarkan dan memperhatikan guru. H. Kategori jawaban yang disampaikan siswa pada saat bimbingan betul merupakan jawaban yang muncul atas dasar akal yang sehat hasilnya adalah adalah 15 siswa belum mampu menyampaikan jawaban dengan baik.

Kesimpulan refleksinya adalah 11 siswa yang kedisiplinannya amat baik, 12 siswa yang kedisiplinannya baik, 10 siswa yang kedisiplinnnya cukup, 1 siswa kedisiplinannya kurang dan 2 siswa kedisplinannya amat kurang sehingga perlu pembinaan lanjutan. Selanjutnya dari rata-rata nilai yang telah diperoleh berdasarkan hasil observasi, yaitu $80 \%$ Hal ini menunjukkan bahwa seluruh siswa memperoleh rata-rata kualifikasi kedisiplinnya baik. Oleh karenanya, bimbingan ini masih perlu untuk dilanjutkan ke siklus berikutnya. 
Bimbingan terus diupayakan agar anak-anak mengenal mana yang baik dan mana yang buruk dengan memberi contoh-contoh kebenaran nyata yang ada dan memadukan dengan cerita-cerita yang kebenarannya sudah dapat dipercaya.

Pelaksanaan observasi dilakukan terus-menerus dengan mengamati keadaan anak-anak, mencek kehadiran mereka pada pagi hari, melihat apakah pakaian yang dikenakan sudah bersih dan rapi, mencek mereka dengan mengamati di kelas, memantau sikap mental mereka dan mencek perubahan yang terjadi pada diri mereka.

Hasil observasi yang dilakukan dapat memberi gambaran yang cukup memuaskan, bahwa selama pengamatan satu bulan lamanya, ada peningkatan yang cukup berarti, semua anak yang diteliti sudah cukup tertib berpakaian, sudah mengenakan ikat pinggang sesuai aturan sekolah, mereka sudah cukup patuh dan menghotmat pada guru-guru, mereka sudah datang dan masuk sekolah tepat waktu, cukuran rambutnya sudah sesuai harapan, mereka dapat berpikir jernih, mereka mampu membuat simpulansimpulan terhadap kebenaran kehidupan yang dialaminya yaitu sebagai murid di Sekolah Menengah Pertama Negeri 2 Singaraja.

Refleksi terhadap hasil pengamatan yang diperoleh adalah:

Dari kategori-kategori yang diobservasi. A. Kategori pakaian sesuai aturan sekolah hasilnya adalah 34 siswa belum sesuai dengan aturan. B. Kategori masuk sekolah/kelas tepat waktu hasilnya adalah 2 siswa belum tepat waktu masuk sekolah/kelas. C. Kategori giat belajar/giat mengikuti bimbingan hasilnya adalah adalah 0 siswa belum giat mengikuti bimbingan. D. Kategori rajin menyelesiakan tugas hasilnya adalah adalah 0 siswa belum rajin menyelesaikan tugas. E. Kategori menggunakan sepatu dan ikat pinggang hasilnya adalah adalah 0 siswa belum menggunakan sepatu dan ikat pinggang sesuai ketentuan sekolah. E. Kategori rambut dicukur rapi hasilnya adalah adalah 0 siswa belum mencukur rambutnya dengan rapi. F. Kategori betul-betul mendengarkan dan memperhatikan guru pada saat bimbingan hasilnya adalah adalah 0 siswa belum disiplin mendengarkan dan memperhatikan guru. G. Kategori jawaban yang disampaikan siswa pada saat bimbingan betul merupakan jawaban yang muncul atas dasar akal yang sehat hasilnya adalah adalah 0 siswa belum mampu menyampaikan jawaban dengan baik.

Kesimpulan refleksinya adalah 34 siswa yang kedisiplinannya amat baik dan 2 siswa yang kedisiplinannya baik. Selanjutnya dari rata-rata nilai yang telah diperoleh berdasarkan hasil observasi, yaitu 98 \% Hal ini menunjukkan bahwa seluruh siswa memperoleh rata-rata kualifikasi amat baik Oleh karenanya bimbingan ini tidak dilanjutkan ke siklus berikutnya.

Dari hasil penelitian siklus I dan siklus II diperoleh data bahwa, terjadi penurunan jumlah pelanggaran tata tetib sekolah. Perubahan prilaku seseorang tidak gampang untuk dilakukan. Perubahan tersebut memerlukan kebiasaan-kebiasaan yang mesti dilakukan dalam waktu yang cukup lama. Kebiasaan anak yang sudah sedermikian rupa dan terbiasa untuk tidak mau belajar dan hanya mau bermain juga tidak mudah untuk diadakan perbaikan. Untuk hal tersebut bimbingan-bimbingan mesti dilakukan, pemberian contoh-contoh perlakuan yang baik, contoh-contoh perlakuan yang dikagumi juga perlu diberikan. Dari hasil yang didapat pada siklus II menunjukkan peningkatan kedisiplinan siswa sudah sesuai harapan dan perubahan yang terjadi sudah cukup signifikan sehingga tidak perlu dilanjutkan ke siklus berikutnya. Dari hasil yang didapat pada siklus II menunjukkan bahwa 34 siswa sudah mencapai nilai amat baik dalam kedisiplinan. Hasil ini telah menjawab tujuan penelitian sehingga penelitian ini diakhiri.

\section{Simpulan dan Saran}

Simpulan hasil penelitian ini adalah bimbingan individual sangat efektif diterapkan untuk meningkatkan kedisiplinan mengikuti tata tertib sekolah. Pada siklus I setelah diamati selama satu bulan sudah berubah, mereka sudah mampu meningkatkan kedisiplinannya dengan 12 orang mendapat nilai baik, 11 orang siswa mendapat nilai amat baik, dengan peningkatan kedisiplinan dari data awal menjadi mencapai 80 \% Selanjutnya pada siklus II telah diperoleh data sesuai harapan yaitu 34 siswa memperoleh nilai amat baik, 2 siswa memperoleh nilai amat baik, walaupun masih ada 2 orang siswa yang perlu diberikan pembinaan dan peningkatan kedisiplinan mencapai 98 \%. Saran disampaikan bagi guru-guru BK agar mencoba cara bimbingan yang peneliti telah lakukan untuk meningkatkan kedisiplinan siswa. Bagi peneliti lain yang ingin mendalami model yang peneliti bawakan dapat mencoba penelitian yang sama terhadap siswa-siswa yang bermasalah. Bagi peneliti yang ingin memverifikasi data hasil penelitian ini bisa melakukan penelitian yang sama untuk memberi masukan, kritik demi kesempurnaan hasil yang telah dicapai. 


\section{Daftar Rujukan}

Abdurrahman, M. (1999). Pendidikan bagi Anak Berkesulitan Belajar. Jakarta: Rineka Cipta.

Anastasi, A. (1976). Psychological Testing. Newyork: Macmillan Publishing.

Arikunto, S. S. S. (2006). Penelitian Tindakan Kelas. Jakarta: PT Bumi Aksara.

Azwar, S. (1996). Pengantar Psikologi Inteligensi. yogyakarta: Pustaka Belajar.

Azwar, S. (2003). Penyusunan Skala Psikologi. yogyakarta: Pustaka Belajar.

Azwar, S. (2004). Penyusunan Skala Psikologi. yogyakarta: Pustaka Belajar.

Badan Standar Nasional Pendidikan. (2007). Peraturan Menteri Pendidikan Nasional Republik Indonesia Nomor 41 Tahun 2007. Jakarta: BSNP.

Bhakti, C. P. (2015). Bimbingan dan Konseling Komprehensif, Dari Paradigma Menuju Aksi. Fokus Konseling, 1(2), 93-106.

Dahar, R. W. (1989). Teori-Teori Belajar. Jakarta: erlangga.

Daryanto. (1999). Evaluasi Pendidikan. Jakarta: Rineka Cipta.

Depdiknas. (2003). Sistem Penilaian Kelas SD, SMP, SMA dan SMK. Jakarta: Dirjen Dikdasmen Tendik.

Depdiknas. (2010). Perkembangan Anak Usia Dini. Jakarta: Direktorat Pembinaan TK dan SD, Dirjen Pendidikan Dasar dan Menengah.

Dewi, Ni Wayan Santha Wiyantari, N. K. S. D. A. W. (2014). Penerapan Konseling Behavioral Dengan Teknik Penguatan Positif Untuk Meningkatkan Perilaku Disiplin Siswa Kelas XI Akomodasi Perhotelan 3 SMK Negeri 2 Singaraja Tahun Pelajaran 2013-2014. Jurusan Bimbingan Konseling, 2(1).

Diatmika, I Gd.Ngr. Angga, I Wy. Sujana, M. P. (2017). Korelasi antara disiplin dalam belajar dengan kompetensi pengetahuan ips siswa kelas iv sd gugus 1 kecamatan mengwi. Journal of Education Technology, 1(3), 156-162.

Dimyati dan Mudjiono. (2001). Belajar dan Pembelajaran. Jakarta: dirjen dikti.

Djamarah, S. B. (2002). Prestasi Belajar dan Kompetensi Guru. surabaya: Usaha Nasional.

Erlina Dewi, I Desak Komang, Ni Ketut Suarni, M. M. (2016). Penerapan Teknik Modeling Untuk Meningkatkan Disiplin Pada Anak Usia 5-6 Tahun. Pendidikan Anak Usia Dini Universitas Pendidikan Ganesha, 3(2).

Hamalik, O. (2002). Psikologi Belajar dan Mengajar. bandung: sinar baru.

Hanum, A. (2015). Bimbingan Pribadi-Sosial Untuk Self-Efficacy Siswa Dan Implikasinya Pada Bimbingan Konseling Smk Diponegoro Depok Sleman, Yogyakarta. Jurnal Hisbah, 12(2).

Hardhianah dan Christiana. (2013). Pemberian Penghargaan Berupa Stiker Gambar dalam Meningkatkan Perilaku Disiplin Anak Usia Dini di TK Bintang Sembilan Lamongan. Jurnal BK UNESA, 4(1).

Isnaini, F. dan T. (2015). Strategi self-management untuk meningkatkan kedisiplinan belajar. Jurnal Penelitian Humaniora, 16(2).

Ita Roshita. (2014). "Meningkatkann Kedisiplinan Siswa Melalui Layanan Bimbingan Kelompok Dengan Teknik Modeling." Jurnal Penelitian Tindakan Kelas, 16(2). 
Megantari, Ni Putu, Ni Nengah Madri Antari, N. D. (2014). Penerapan konseling bahavioral dengan strategi self management untuk meningkatakan disiplin belajar siswa kelas $\mathrm{x}$ mia. Jurusan Bimbingan Konseling, 2(1).

Miles, Matthew, B. D. A. M. H. (1992). Analisis Data Kualitatif. Jakarta: universitas indonesia.

Nursetya, Sikha Basti, E. S. K. (2014). Upaya meningkatkan kedisiplinan siswa kelas x sma negeri 1 wates dalam mengikuti pembelajaran penjasorkes melalui reinforcement (penguatan). Jurnal Pendidikan Jasmani Indonesia, 10(2).

Saputra, S. T. dan P. (2012). "Pengaruh Disiplin Belajar dan Lingkungan Teman Sebaya Terhadap Prestasi Belajar Mahasiswa." Jurnal Pendidikan Akuntansi Indonesia, 10(1).

Simanungkalit, D. (2017). Upaya meningkatkan kedisiplinan siswa melalui layanan penguasaan konten dengan teknik modelling pada siswa kelas vii smp negeri 8 tebing tinggi. Sej, 7(1).

Sulasmi, Putu Ayu Oka, M. S. G. S. (2014). Penerapan konseling behavioral dengan teknik modeling untuk meningkat perilaku disiplin siswa di sma bhaktiyasa singaraja tahun pelajaran 2014-2015. Jurnal Ilmiah Bimbingan Konseling Undiksha, 2(1).

Widana, N. N. W. S. S. (2016). Pengaruh disiplin belajar dan lingkungan keluarga terhadap prestasi belajar ilmu pengetahuan sosial siswa kelas viii smp negeri 3 singaraja. Program Studi Pendidikan Ekonomi, $7(2)$.

Yuliyantika, S. (2017). Analisis faktor-faktor yang mempengaruhi disiplin belajar siswa kelas x, xi, dan xii di sma bhakti yasa singaraja tahun pelajaran 2016-2017. Jurusan Pendidikan Ekonomi, 9(1). 